\title{
Combating global hunger and forging a path to food sovereignty
}

\author{
O combate à fome global e a conquista do caminho para a \\ soberania alimentar
}

\author{
Combatiendo el hambre global y forjando un camino para la \\ soberanía alimentaria
}

\begin{abstract}
FOOD AS A HUMAN RIGHT: COMBATTING GLOBAL HUNGER AND FORGING A PATH TO FOOD SOVEREIGNTY. Schanbacher WD. Santa Barbara: Praeger; 2019. 212 p. (Series: Praeger Security International). ISBN 978-1-44086177-2.
\end{abstract}

doi: 10.1590/0102-311X00208719

The author is a scholar of religious affairs and social ethics, with a doctor's degree from Claremont Graduate University, California, USA.

The main importance of this book is the relation of power with culture in the Anthropocene environment and the struggle of this militant author to eradicate hunger and to associate hunger with bad public policy and neglect, showing technical and ethically sustainable arguments.

For the author, wealthy citizens of the world are complicit in the world's hungry and thus contribute directly to violation of human rights. They are complicit supporting an unfair global food system created by the International Monetary Fund (IMF), World Bank Group, and World Trade Organization (WTO) trade agreements, and because they elect the political leaders who have the power to influence economic and trade policies, with the ability to change the system, but do not use it.

For example, to discuss "hunger eradication" and millennium pandemic diseases - such as diabetes and obesity caused by malnutrition -, as well as the proliferation of genetically modified organisms (GMO), creates food insecurity.

Nowadays, global institutions negatively influence developing countries and their trade agreements, and these countries have little to say in policy-making.

Food integrity should be focused as the ideal measure of sustainability and environmental resilience, combined with food safety and sovereignty for the production and direct distribution of safe food 1 .

Rather than resorting to strategies such as charity or the work of non-governmental organizations (NGO), this book argues that effective and realistic public policies should be implemented in order to provide to developing countries veto power and self-awareness, so they would be able to express opinions based on their micro-realities and to improve their situation in their countries and in the particular set of their own communities.

Throughout the chapters of this book, readers are presented to different philosophical, moral, and literary texts that can be applied to the topic of food and to the global food system, and thus, indirectly related to the central theme of food sovereignty. The book argues that the best way forward is to enable developing countries to determine the agricultural and food policies they consider best for their communities and local farmers.

Although it may not be apparent, the author tries to present interdisciplinary knowledge and transversality in the exam of reality to under- 
stand the complexity of the global food system and to encourage the emerging interest of scholars in these different areas.

Part of the book goal is to guide the reader to understand and to provide them with arguments to discuss the concept of food sovereignty and the concept of "food itself" towards a more humane and righteous food system. The heart of the food sovereignty movement is the notion that the cultural importance of food itself should be reinforced rather than thinking of it as a simple commodity. Food is considered a "foundation of life" and it has a deeper meaning for those who produce it.

The first chapter briefly presents the current status of the global food system in the contextual nexus of terms such as "globalization", "development", "food security" and what many call "global food regime". The author states that globalization is not a new process, it has been evolving since the early years of human civilization and that "Cultures" share their belief systems and food traditions.

Chapter 2 criticizes the important organizations, their strategies, and trade agreements that created the global food system as we know it. In particular, this chapter signals the failure of several global food trade agreements ratified or proposed by organizations such as the IMF, the World Bank Group and the WTO.

Chapter 3 presents the food sovereignty movement and Chapter 4 investigates the phenomenon of "land grabbing". The issue of land grabbing is particularly important to understand the concept of food sovereignty. Land is essential for survival and it is imperative that small farmers and peasants have control over this essential resource (inputs) according to their needs: a physical reality of which they are well acquainted (they have greater and better knowledge on the use of land resources).

Chapter 5 presents an examination of a controversial issue - namely the progressive and expansionist influence of agribusiness - linked to the corporatization of the global food system. The logic is that as mass-produced agriculture grows, national governments and global farmers will be subjected even more to market demands.

In addition to the food system that denies the access of food to people by centralization, the policy of industrial agriculture largely trivializes the dangers of GMO monocultures to biodiversity, weakening food systems. This hegemonic culture of transgenic food production is present throughout the production chain 1.

Chapter 6 focuses on one of the most important issues nowadays, regarding human rights and food sovereignty, the access to water (as an essential input). Whether by the dumping of human waste into the oceans or contamination by modern industries, producing harmful chemical runoff, water is increasingly under siege. As water becomes scarcer in different regions of the world, it serves as a source of political and cultural conflict.

Chapter 7 summarizes the themes and issues previously developed and presents the role that human rights can play, which is to act critically in the unfolding concepts of global "food justice" and "food sovereignty". The author argues that human rights critics discuss that those are manmade systems and therefore cannot be the basis for understanding how we should treat the environment and other human beings.

The hegemonic culture of the "sustainable development" model is also an affront to human rights, as it follows strict rules of the market economy tending to expose the social costs of economic growth and further widen the gaps between poor and rich countries.

This development model, in addition to perpetuating social inequality, continues to degrade the planet. Sachs's work 2 - based on the Anthropocene's historical-geological conceptual defense - emphasizes economic growth supported by the factors of production, nature and clean technology, but his book does not adequately address the immediate need to contain consumption and waste: checks and balances necessary to improve the economic model itself.

Chapter 8 ends with an ethical analysis of the topics addressed throughout the book. Many issues presented seem controversial, deserving constant and reasonable debate about the complexity of the global food system. The concepts and various social movements associated with food sovereignty provide resources for continuous reflection on how to deal with global systemic inequities and inequalities. 
With an ethical analysis of the topics covered throughout the book, Chapter 8 offers to readers a choice based on a careful distinction between two ways of framing issues on global food system, food justice and human rights.

This book not only provides an insightful and sometimes sharp critique of the current global food system, but also provides suggestions for possible solutions to the global problems of poverty and hunger. This book should be recommended for food law regulators, critical scholars of hunger and food security and public health; as well as for policy-makers, to recognize various global public policies with caution and to learn to understand them as likely systemic disruptions that undermine both quality of life and sustainability of most people and cultures, including starving, excluded ones unattended by them.

Hermes de Andrade Júnior 1,2

1 Universidade Católica Portuguesa, Braga, Portugal.

2 Universidade de Vigo, Vigo, España.

handradejunior@gmail.com

\section{Additional information}

ORCID: Hermes de Andrade Júnior (0000-00023667-1354).

1. Steier G. Advancing food integrity: GMO regulation, agroecology, and urban agriculture. New York: CRC Press Inc.; 2018.

2. Sachs JD. The age of sustainable development. New York: Columbia University Press; 2015. 